\title{
On the Entanglement between Sociology and Architecture in Spatial Research
}

\author{
Séverine Marguin
}

Editorial Summary: Coming from a background of sociology, but taking part in the interdisciplinary research network »Re-figuration of Space«, Séverine Marguin describes the »design turn " as a driving force for new directions in the humanities and natural sciences as well as a starting point for new formats and procedures in scientific investigation. She emphasizes the potential of cross-disciplinary research for either discipline involved, as it fosters new insights beyond disciplinary framings. " $0 n$ the entanglement between sociology and architecture in the field of spatial research « highlights the »design turn« in social sciences as a catalyst for the incorporation of design-based procedures into the humanities, opening new possibilities to reconfigure the thematic field, its methodologies, and its forms of research. [Katharina Voigt]

Keywords: Design Turn; Interdisciplinarity; Transdisciplinarity; Sociology.

\section{A Broad Interdisciplinarity between Sociology and Architecture}

Interdisciplinarity is experienced in various forms. Following Julie Thompson Klein's typologies, different patterns of consensus and debate can be identified - stemming from the first major classification scheme in 1970 to recent taxonomies. Klein »compares similarities and differences in a framework of multidisciplinary juxtaposition and alignment of disciplines, interdisciplinary integration and collaboration, and transdisciplinary synthesis and trans-sector problem solving (Klein 2017: 23). This research project addresses a specific form of interdisciplinarity between design and sociology and, in particular, between architects, planners, and sociologists. It is a broad interdisciplinarity, in which the disciplinary integration proves to be complex, inasmuch as it concerns »disciplines with little or no compatibility such as sciences and humanities [which] have different epistemological paradigms and methodologies « (Klein 2017: 34). Is such an integration even possible? What form (whether multidisciplinary, interdisciplinary or 
transdisciplinary) is needed in everyday research practice? And what consequences can such interdisciplinary encounters have for the respective disciplinary understandings and epistemic cultures (Knorr-Cetina 2001; Keller/ Pofferl 2018)?

In order to open the debate, I would like to begin with a small narration about a personal interdisciplinary experience between sociology and architecture, in order to show the complexity it involves. In 2019 I worked as a scientific ethnographer and developed a design-based, experimental research design in collaboration with an architect and an interaction designer to analyze the effect of space on the research practices of our colleagues in a so-called Cluster of Excellence (Marguin/Rabe/Schmidgall 2019). Originally, the project was conceived by the designers together with a spokesperson from the cultural studies department with the aim of finding spatial solutions to increase the productivity of the researchers in the excellence cluster. We were to design spatial settings, test them with quantitative tracking measurements and finally evaluate them. The project functioned as a »showcase«-project of the cluster and received a lot of visitors (e.g. from the field of university and research politics). After forming our team, we decided as project staff to reorient the project and to push it more in the direction of a qualitative experimental basic research project, for which we interfered with irritations as well as optimizations across the 18 different settings. This "problematization" was welcomed by the supervisors - but only up until the time of the new proposal for the next Cluster of Excellence, when they urgently asked us for concrete and proved solutions. In contrast, our methodological as well as theoretical and empirical contribution to spatial research did not appear to count or be of value. One year later and outside of the already completed cluster, we published our project publication as a team and devised five concrete statements at the end of our detailed book, which were specifically addressed to the designers of research spaces (Marguin/ Rabe/Schmidgall 2019: 186-188).

This anecdote exemplifies how the recipient and the purpose of interdisciplinary research, which oscillate between different logics, can remain ambivalent right up to the end for both the participants and more generally for such a design-focused research project within the framework of a Cluster of Excellence, funded by the German Research Foundation (DFG). This anecdote - in its complexity - allows me to develop a space to reflect on polycontextural knowledge production at the interface between design and sociology (Marguin 2021). 


\section{Scientification of Architecture and Creativization of Sociology}

The integration of design disciplines (such as art, design, architecture) into the classical (so far mainly natural and humanities) sciences has become an increasingly important topic in the literature on the history of science and cultural studies. Schäffner (2010) and Mareis (2010) welcome this as a desirable development and assign design an »integrative strength (Kraft) for the different scientific disciplines « (Schäffner 2010: 33). Although increasingly occurring, such a development has not yet been investigated - not for the social sciences nor for architecture.

Based on historical analysis, I claim that the design turn leads to new forms of interdisciplinary collaborations and, in my case especially, the referencing between the disciplines of architecture and sociology. In a first step of the research, I outlined the different forms of historical referencing and collaborations between architects and sociologists since their respective disciplinary foundations. In doing so, I addressed the respective positions held by architectural research in sociology and by sociology in architectural research, both at the level of the disciplinary object itself (»architecture» and »society«) and at that of the disciplines themselves (do architectural researchers work with sociological knowledge or even sociologists and viceversa?). The result of this literature research conveys that despite repeated attempts at rapprochement, collaborations did not become sustainable until the early 2000 s, when, in the course of the so-called »design turn«, fundamental new aspects could be observed, pointing to an integrative quality of both disciplines (Marguin 2021).

This new integration as a bold collaboration massively challenges our respective understanding of knowledge and its relationship to society and even more fundamentally to reality. How do we want to generate knowledge? For whom? For what purpose? There is a disciplinary divide of viewpoints. It is what makes current integrative collaboration so difficult but also so exciting and relevant. These are precisely the normative questions of scientific theory that I am now empirically exploring and whose complex entanglement I would like to address in the sense of an empirical theory of science (Knoblauch 2018). For this multiscale investigation, I pursue a mixedmethod approach, consisting of a micro-sociological ethnographical part at the CRC 1265 »Re-Figuration of Spaces" (TU Berlin) and a macrosociological component at the field level. Within the ethnographic investigation at the CRC, I observe the everyday interdisciplinary collaboration 
between sociologists, planners, and architects and analyze the challenges they face, whether as obstacles or productive frictions (Marguin/Knoblauch 2021). These challenges unfold on practical, methodological, scientific and institutional levels. On a macro-sociological level, the research project aims to illustrate the structure of the relational field of architectural research and identify potential linkages to social-science approaches as well as to other actors (i.e. to practitioners). To this end, I conduct interviews with experts on one hand and create different databases on architectural researchers, and on research projects in the field of architectural research in the Germanspeaking academic field on the other.

The first observation that emerges from my research, both at the Cluster of Excellence and at the CRC 1265, is that there are two parallel converging tendencies: the scientification of architecture and the creativization of sociology. These two tendencies are both somehow explanations and facilitators of such interdisciplinary cooperation.

The debate about the scientification of architecture is by no means a new phenomenon. Rather, it has marked the academicization of the discipline since the 16th century and especially since architecture was integrated into the technical universities from the second half of the 19th century onwards. It has been recurrent throughout the 2oth century - whether in the design methods movements in Ulm, or in the 1970s' student movements, or in the digitalization of design in the 1990s. The ambivalence between a free, artistic, and subjective design practice and the longing for systematization is an important component of the epistemic culture of architects and architectural researchers. Following Kurath (2015), two modes of researching in the academic field of architecture can be observed: The first mode is aligned with the validity criteria and scientific understanding established in other disciplines - whether philosophical, sociological, historical or from the field of engineering sciences. Within our CRC, this mode is quite visible in the great interest of the architects in developing a methodological discourse that follows more sociological rules. This also has an institutional background; architects have to defend their position, especially within the faculty, thereby needing doctoral theses, acquisition of third-party funds, and peer-reviewed articles to remain competitive. An opposite tendency is the legitimization of design research as a concept encompassing design practice as a research practice. However, in German-speaking countries - unlike in English-speaking countries, for example - it is extremely controversial and characterized by a heterogeneity of positions. 
At the same time, I would like to put forward the thesis of a creativization of sociology, following Reckwitz's social diagnosis of the »dispositif of creativity« $(2012,2016)$. In our CRC 1265, sociologists hope to develop new, innovative methods of spatial research from the interdisciplinary work by integrating visual-mapping methods from architecture and planning into sociology among other things (Baxter et al. 2021). Beyond the boundaries of the CRC, there are an increasing number of initiatives in the Germanspeaking field that are interested in integrating artistic and design methods into social research - whether in the field of sociology or anthropology (Wildner 2015; Fariàs/Criado 2019; Estalella/Criado 2019). This shift of sociology toward design can be interpreted as an »expansion of its innovation zone« (Rammert et al. 2016). In fact, this notion of creativity is thought of as a means of innovation for social research: The hope is that something new will emerge from the collectively and strategically provoked dissonances. It seems important, here, following Rammert, to critically question whether the creativization process in sociology can be regarded as "an imperial expansion of economic innovation criteria or [rather] a liberal extension to social innovations « (Rammert et al. 2016:4). Or more simply formulated: why should sociology become more creative? At this stage of my investigation it remains unclear whether this imperative of the renewal of sociology around the "practice and semantics of creativity« (Hutter et al. 2016: 28) is rather, in the Bourdieusian sense, field-internally driven, or if it responds to fieldexternal factors.

I present both tendencies equally here, despite the unbalanced tendency, which favors sociology over the design. The scientificiation of architecture is a common tendency, while the creativization of sociology only exists in its initial stages and at the periphery.

\section{A Design Turn for the Social Sciences}

In terms of contemporary diagnosis, such converging developments largely tie in with the need for a "transformative science (Schneidwind/SingerBrodowski 2014), understood as the function of science to restructure social areas of life, including changing people's behavior. For this challenge of science's transformative performativity, the design disciplines are relatively highly valued because they include the competency to consider potential changes and reflect on the performativity of their own knowledge production into society. But what does it mean and imply for sociology and its 
potential to become more creative? And for architecture to become more scientific? In other words, what kind of challenges do such mutual integrative adjustments bring? The pitfalls of such cooperation between design and social science become visible in the interdisciplinary everyday collaboration. The empirical investigation shows that the attempt to appropriate the structural logics of the other field leads to a seemingly inevitable conflict, insofar as the respective logics of the academic fields contradict each other.

In the ethnographical investigation, scholars address their feeling of alienation from their field-specific practice. Designers clearly convey that their participation in a basic research project is not sufficient or remains irrelevant to their peers, if it is not followed by an operative and projective translation into society. The inconsequence, or rather the absence of the project's finality, acts as an insurmountable disadvantage for recognition in their community. For the sociologists, however, it creates the opposite unease: The need for action is perceived as an external compulsion that implies a loss of autonomy. Embedded in its structural logic, the sociologists link it directly to the current debates on the new relationship or »contract between social sciences and society « (Weingart 2008), which should no longer be characterized by disinterest and independence but rather be guided by socially relevant political or economic mandates. This highlights the heteronormatization tendencies at work and points to the controversial debate on the so-called »Mode 2 « or triple helix of knowledge production (Gibbons et al. 1994), which suggests an intertwining of scientific epistemology, entrepreneurial application orientation, and efficiency-based strategies of problem solving - and clearly endangers the basic scientific orientation of the social sciences (Gingras/Heilbron 2015). Conflicting polarities are identified during the investigation: practice vs. theory; action or application research vs. basic research; synthetic vs. analytical science. Terms such as action, application, practice, and mission will be almost equated. The amalgam gives the (deceptive) impression of a clear duality as well as an irreconcilable discrepancy between the disciplines.

However, this schematic, polarizing duality is not satisfactory. As the aforementioned anecdote demonstrated in an exemplary way, the positions of the researchers, whether sociologists or designers, are much more complex. Therefore, I suggest breaking the polarity shown above and complexifying it. From the analysis of the disciplinary structural logics, the following two axes become clear: in the sociological field, it is primarily a question of the autonomy/heteronomy of the social sciences, while in the 
field of architectural research, it is more a question of the compatibility of research and design. The relation of these different elements enables the expansion from the one-dimensional restricted polarity to a two-dimensional space of interdisciplinary spatial research (see fig. on following page).

This gives rise to four different understandings of interdisciplinary research: autonomous with design; autonomous without design; heteronomous with design; heteronomous without design. This spatial modeling is not intended to show ideal types but rather a continuum of research understandings that are relatively more autonomous or heteronomous, or contain relatively or no design aspects. This notion enables thinking about a research practice with design aspects that, despite its dimensions of application, practice or action, would nevertheless take on autonomous traits in its orientation and execution (see the red square on the diagram). A preliminary placement of representatives from the interdisciplinary field of urban and spatial research was realized on the diagram to illustrate the differentiated positioning. It should not be overlooked, however, that a strong imbalance of power is at work here, insofar as the field of sociology has considerably more power in a scientific or academic context than the field of architectural research, which is still in its infancy. In fact, the Design Turn is still at its very beginning and, although very promising, has to contend with greater disadvantage in the classical sciences, especially in the social sciences.

\section{Conclusion}

In this paper, I present the initial results of an empirical investigation that I am currently conducting on the relationship between design and the social sciences on the basis of an ethnographic inquiry of the cooperation between architects, planners, and sociologists. I first discuss the current favorable tendencies of approximation between these disciplines, namely a scientification of architecture and a certain creativization of sociology before tackling the main challenges of such cooperation concerning the divergent understanding of knowledge and science.

In order to go beyond the common but deceptive duality between design vs. science; practice vs. theory; action or application research vs. basic research; synthetic vs. analytical science, I have proposed to break down the polarity and complexify it, thereby relating the structural logics to both fields. Such a spatial-visual modeling, which creates the possibility of autonomous creative-social-scientific research, however, raises many questions. 


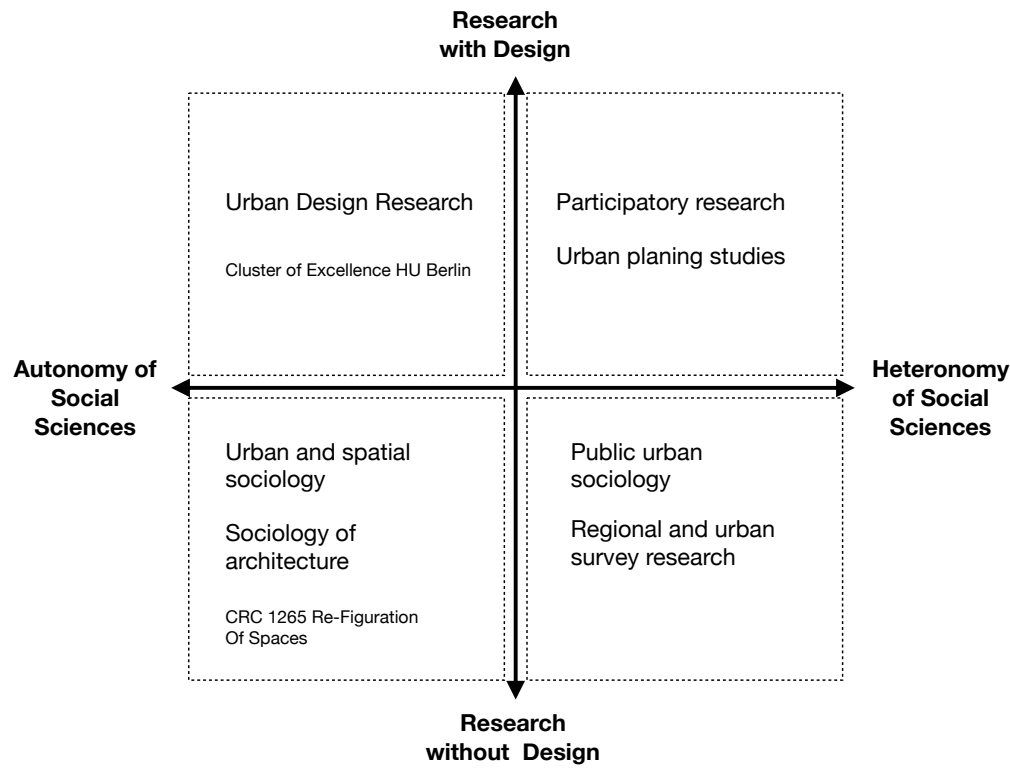

»Modelling a Two-Dimensional Space of Interdisciplinary Spatial Research" CRC 1265 Re-Figuration of Spaces.

Graphics: Séverine Marguin, 2020. 
The first is the question of autonomy. If I have so far dealt exclusively with the autonomy of the (social) sciences (Bourdieu 1975, 1997, 2001; Bernhard/ Schmidt-Wellenburg 2012a, b), the autonomy of architecture must also be considered. Based on the work of Biau (1998) and Aigner (2007), field theory does indeed lend itself well to the analysis of architecture, insofar as it can be understood as a cultural asset. Can one therefore speak of a parallelism between the understandings of autonomy in the social sciences and in architecture? The second question concerns the career possibilities of such hybrid knowledge producers and the risk of their marginalization: in fact, the investigation provides many indications that disciplinary logics continue to be of a strange importance in career formation. A deviation from the disciplinary rules of the game may lead to a dead end, also because what has been learned from interdisciplinary cooperation can no longer be sealed off. The only solution for hybrid knowledge producers is therefore to influence the rules of the game in their own field in order to increase the acceptance of alternative approaches.

\section{References}

Aigner, Anita (2007): »Architektur als

Feld«, presented at the conference »Profession, Habitus und Wandel «, Humboldt Universität Berlin.

Baxter, Jamie Scott/Marguin, Séverine/ Mélix, Sophie/Schinagl, Martin/Sommer, Vivien/Singh, Ajit (2021): »Hybrid Mapping: Visual Methods at the Intersection of Sociospatial Research and Design«, in: SFB 1265 Working Paper No. 5 Berlin.

Bernhard, Stefan/Schmidt-Wellenburg, Christian, eds. (2012a): Feldanalyse Als Forschungsprogramm 1. Der Programmatische Kern, Wiesbaden: Springer VS.
Bernhard, Stefan/Schmidt-Wellenburg, Christian, eds. (2012b): Feldanalyse Als Forschungsprogramm 2. Gegenstandsbezogene Theoriebildung, Wiesbaden: Springer VS.

Biau, Véronique (1998): „Stratégies de positionnement et trajectoires d'architectes«, in: Sociétés contemporaines 29(1), 7-25.

Bourdieu, Pierre (1975): »The Specificity of the Scientific Field and the Social Conditions of the Progress of Reason «, in: Social Science Information 14(6), 19-47. 
Bourdieu, Pierre (1997): Les usages sociaux de la science: Pour une sociologie clinique du champ scientifique, Paris, INRA Editions. German translaton: Vom Gebrauch der Wissenschaft. Für eine klinische Soziologie des Wissenschaftlichen Feldes, transl. by Stephan Egger, Konstanz: UVK Verlagsgesellschaft, 1998.

Bourdieu, Pierre/Wacquant, Loïc [2001]: Science de la science et réflexivité, Paris: Éditions Raisons d'agir. - English translation: Science of Science and Reflexivity, Cambridge: Polity Press, 2004.

Estalella, Adolfo/Criado, Tomás Sánchez (2019): »DIY Anthropology. Disciplinary Knowledge in Crisis«, in: ANUAC Journal of the Italian Society of Cultural Anthropology 8(2), 143-65.

Fariàs, Ignacio/Criado, Tomás Sánchez (2019): »Erfahren. Experimente mit technischer Demokratie in Entwurfskursen«, in: Séverine Marguin/Henrike Rabe/Wolfgang Schäffner/Friedrich Schmidgall (eds.) Experimentieren. Einblicke in Praktiken und Versuchsaufbauten zwischen Wissenschaft und Cestaltung, Bielefeld: transcript Verlag, 67-81.

Gibbons, Michael/Limoges, Camille/ Nowotny, Helga/ Schwartzman, Simon/ Scott, Peter/Trow, Martin (1994): The New Production of Knowledge: The Dynamics of Science and Research in Contemporary Societies, London: Sage Publishers.

Gingras, Yves/Heilbron, Johan (2015): »La résilience des disciplines «, in: Actes de la Recherche en Sciences Sociales 210(5), 4-9.

Hutter, Michael/Knoblauch, Hubert/ Rammert, Werner/Windeler, Arnold (2016): »Innovationsgesellschaft heute«, in: Werner Rammert/Arnold Windeler/ Hubert Knoblauch/Michael Hutter (eds.), Innovationsgesellschaft heute, Wiesbaden: Springer Fachmedien Wiesbaden, 15-35.

Keller, Reiner/Poferl, Angelika eds. (2018): Wissenskulturen der Soziologie, Weinheim; Basel: Beltz Juventa.
Klein, Julie Thompson (2017): »Typologies of Interdisciplinarity: The Boundary Work of Definition«, in: The Oxford Handbook of Interdisciplinarity, Oxford: Oxford University Press.

Knoblauch, Hubert (2018): »Von Der Reflexiven Methodologie Zur Empirischen Wissenschaftstheorie«, in: Leila Akremi/ Nina Baur/Hubert Knoblauch/Boris Traue (eds.), Handbuch Interpretativ Forschen, Weinheim: Beltz Juventa, 226-244.

Knorr-Cetina, Karin (1995): »Laboratory Studies. The Cultural Approach to the Study of Science«, In: Sheila Jasanoff/ Gerald Markle/James Peterson/Trevor Pinch (eds.), Handbook of Science and Technology, Thousand Oaks, CA: Sage Publishers.

Kurath, Monika (2015): »Architecture as a Science: Boundary Work and the Demarcation of Design Knowledge from Research «, in: Science \& Technology Studies 28(3), 81-100, doi: 10.23987/sts.55343

Mareis, Claudia (2010): »EntwerfenWissen-Produzieren. Designforschung im Anwendungskontext«, in: Claudia Mareis/Cesche Joost/Kora Kimpel (eds.), Entwerfen-Wissen-Produzieren. Designforschung im Anwendungskontext, Bielefeld: transcript Verlag, 9-32.

Marguin, Séverine, Henrike Rabe, and Friedrich Schmidgall (2019): The Experimental Zone. An Interdisciplinary Investigation on the Spaces and Practices of Collaborative Research, Zurich: Park Books.

Marguin, Séverine (2021): »Architecture and Sociology: A Sociogenesis of Interdisciplinary Referencing «, in: Forum: Qualitative Social Research, special issue The Re-Figuration of Spaces and Cross-Cultural Comparison. 
Marguin, Séverine (2021):

»Interdisziplinarität als polykontexturale Wissensproduktion. Über die Kollaboration zwischen SoziologInnen, ArchitektInnen und PlanerInnen«, in: Martina Löw/Volkan Sayman/Jona Schwerer/Hannah Wolf (eds.), Am Ende der Globalisierung. Über die Re-Figuration von Räumen, Bielefeld: transcript Verlag.

Marguin, Séverine/Knoblauch, Hubert (2021): »Empirische Wissenschaftstheorie. Wissenschaftsethnografie, experimentelle Methodenentwicklung und Sensitizing Visits im SFB 1265 ReFiguration von Räumen«, in: Martina Löw/ Volkan Sayman/Jona Schwerer/Hannah Wolf (eds.), Am Ende der Clobalisierung. Über die Re-Figuration von Räumen, Bielefeld: transcript Verlag.

Rammert, Werner/Windeler, Arnold/ Knoblauch, Hubert/Hutter, Michael (2016): »Die Ausweitung der Innovationszone«, in: Werner Rammert/Arnold Windeler/ Hubert Knoblauch/Michael Hutter, Innovationsgesellschaft heute, Wiesbaden: Springer Fachmedien, 3-13.

Reckwitz, Andreas (2012): Die Erfindung der Kreativität. Zum Prozess gesellschaftlicher Ästhetisierung, Frankfurt am Main: Suhrkamp.

Reckwitz, Andreas (2016): »Das Kreativitätsdispositiv und die sozialen Regime des Neuen«, in: Werner Rammert/ Arnold Windeler/Hubert Knoblauch/ Michael Hutter, Innovationsgesellschaft heute, Wiesbaden: Springer Fachmedien, 133-153.

Schäffner, Wolfgang (2010): »The Design Turn. Eine Wissenschaftliche Revolution Im Geiste Der Gestaltung «, in: Claudia Mareis/Cesche Joost/Kora Kimpel, Entwerfen - Wissen-Produzieren Designforschung im Anwendungskontext, Bielefeld: transcript Verlag, 33-46.

Schneidewind, Uwe/Singer-Brodowski, Mandy (2014): Transformative Wissenschaft. Klimawandel Im Deutschen WissenschaftsUnd Hochschulsystem, Marburg: Metropolis.
Weingart, Peter (2008): »Ökonomisierung der Wissenschaft«, in: NTM Zeitschrift für Geschichte der Wissenschaften, Technik und Medizin 16(4), 477-484, doi: $10.1007 /$ s00048-008-0311-4

Wildner, Kathrin (2015): »Inventive Methods. Künstlerische Ansätze in Der Ethnographischen Stadtforschung«, in: Ethnoscripts 17(1), 168-185. 


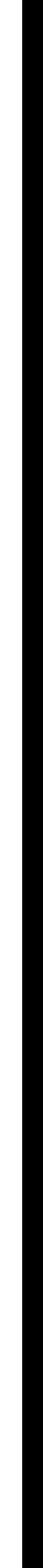

